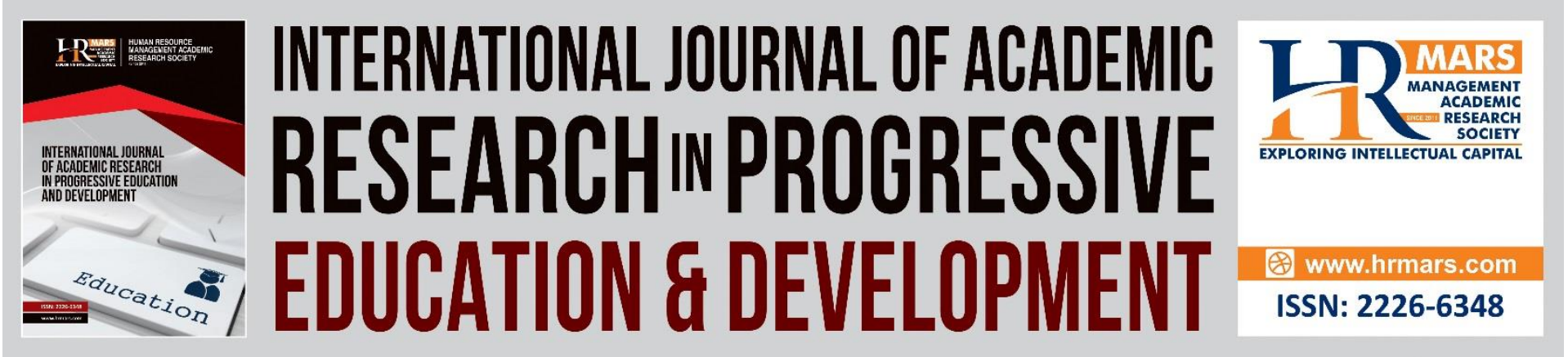

\title{
A Systematic Review of Teachers' Perception Towards ICT Integrations in Mathematics Classroom
}

Teoh Hui Fung, Siti Mistima Maat

To Link this Article: http://dx.doi.org/10.6007/IJARPED/v10-i3/10922

DOI:10.6007/IJARPED/v10-i3/10922

Received: 09 July 2021, Revised: 12 August 2021, Accepted: 29 August 2021

Published Online: 22 September 2021

In-Text Citation: (Fung \& Maat, 2021)

To Cite this Article: Fung, T. H., \& Maat, S. M. (2021). A Systematic Review of Teachers' Perception Towards ICT Integrations in Mathematics Classroom. International Journal of Academic Research in Progressive Education and Development, 10(3), 1349-1363.

Copyright: (C) 2021 The Author(s)

Published by Human Resource Management Academic Research Society (www.hrmars.com)

This article is published under the Creative Commons Attribution (CC BY 4.0) license. Anyone may reproduce, distribute, translate and create derivative works of this article (for both commercial and non-commercial purposes), subject to full attribution to the original publication and authors. The full terms of this license may be seen

at: http://creativecommons.org/licences/by/4.0/legalcode

Vol. 10(3) 2021, Pg. 1349 - 1363

http://hrmars.com/index.php/pages/detail/IJARPED

JOURNAL HOMEPAGE

Full Terms \& Conditions of access and use can be found at http://hrmars.com/index.php/pages/detail/publication-ethics 


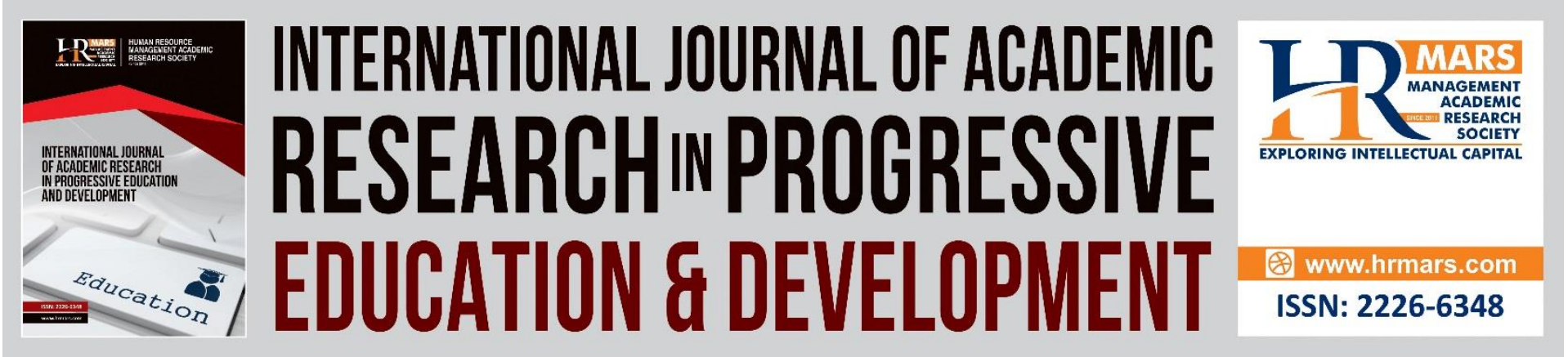

\title{
A Systematic Review of Teachers' Perception Towards ICT Integrations in Mathematics Classroom
}

\author{
Teoh Hui Fung, Siti Mistima Maat \\ Faculty of Education, The National University of Malaysia \\ Email: p105829@siswa.ukm.edu.my, sitimistima@ukm.edu.my
}

\begin{abstract}
In the 21st century, the continuous integration of information communication technology (ICT) makes the professional development of mathematics teachers face new huge opportunities and challenges. Digitalization, showing infinite charm of development, it has become an important symbol of modernization in mathematics education. Hence, this articles review is to study about teachers' perception towards ICT integrations in mathematics Classroom. Articles access from 2017 -2021 across two databases SCOPUS and WOS (Web of Science) were referred. This study used PRISMA Model (Preferred Reporting Items for Systematic Reviews and Meta-Analyses). A total of 697 articles were found however only 30 articles were identified that qualified and were accepted in this study. The result of SLR show that the majority country study is from Turkey follow by United States. The result shows that the frequency of studies in this field is uniform for 2017 to 2019, but it is increasing in year 2020. This might be cause by the Covid-19 pandemic that force the education system to be conducted online. In terms of methodology, the most research design that had been carry out is case study and conducted qualitatively. The findings can be used in guiding future research needed to be conducted concerning the integration of ICT in mathematics classroom.

Keywords: Perception, ICT, Technology, Mathematics, Teachers, Systematic Review
\end{abstract}

\section{Introduction}

Over the years, educators have been exploring different strategies and methods to improve the quality of education and the overall learning process (Marbán \& Mulenga, 2019). In the development of primary and secondary education, the application of information and communication technology (ICT) is becoming more and more important. Teachers' ICT application ability refers to the ability of teachers to use emerging technologies based on computer technology and supplemented by network media and related subject teaching software. Since, educational technologies have entered the classroom and participated in teachers' teaching and learning process. Many teachers actively respond to this trend change, but some teachers hold different views. Basic knowledge and basic skills in ICT are important to update educational concepts and improve teachers' knowledge and teaching ability. 
Therefore, it is necessary for us to conduct research on these aspects, specially about teachers' perception towards ICT.

In recent years, with the help of the Internet and information technology, an unstoppable revolution has taken place in the classroom. Many researchers have conducted varies studies and reviews about teachers' perception towards ICT integration in classroom. Some studies have reported that teachers have a positive view of integrating ICT in classroom and believed ICT makes learning interesting (Ali, 2018; Ardani et al., 2018; Belay et al.,2020; Katsarou, 2020; Nasreen \& Chaudhary, 2018; Redmond \& Lock 2019; Sang et al., 2018; Taghizadeh \& Yourdshahi, 2020; Trujillo-Torres et al., 2020; Zubković et al., 2017). On the other hand, previous findings also revealed that teachers also had negative perceptions in integrating ICT (Banda et al., 2020; Jepkorir, 2017). This might be affected by teachers' low ICT ability, lack confidence about using ICT in the classroom or lack of training in ICT mediated methodologies. According to Mensah (2017), mathematics teachers were favourable to the use of ICT in teaching mathematics and most of the teachers were knowledgeable about using ICT such as Microsoft word, power point, excel and calculators. Many studies have been done by researchers about integration ICT either in mathematics classroom or mathematics subjects (Umugiraneza et al., 2018; Mustam \& Adnan, 2019; Kim et al., 2019; Ogegbo \& Aina, 2020; Trujillo-Torres et al., 2020). Their findings indicated that the perception of teachers is positive towards ICT and they have also had positive mind-set about using ICT in teaching mathematics.

The integration of ICT in mathematics education provide comprehensive teaching for mathematics teachers with interactive teaching methods. This study will discuss the article selection criteria and search the process for systematic literature review. This systematic literature review was conducted to further identify teachers' perception towards ICT integration in mathematics classroom. Together with the article's data collection methods and data analysis, the article will be critically evaluated. Information and communications technology (ICT) play an importance role in education, it helps students to visualize mathematical concepts that they might not be able to imagine. In this technology generation, it is our best moment to integrate ICT into mathematics classroom using the devices we have. Different teachers may have different thoughts on ICT integrations and examining the literatures, we are able to classify and make conclusion on teachers' perceptions towards ICT in mathematics classroom.

\section{Research Questions}

The purpose of this study was to explore and review the relevant aspects with teachers' perception in mathematics classroom towards the integration of ICT research. Therefore, a systematic literature highlights is done to answer the following questions:

1. How is teachers' perception studied in empirical research of mathematics education?

2. What is the study field covered by the researchers in conducting the study of teachers' perception towards ICT integration in mathematics classroom?

\section{Methodology}

The highlights of this systematic literature reviews will be guided using PRISMA (Preferred Reporting Items for Systematic Reviews and Meta-Analyzes). Model PRISMA is a quality guideline because of its process are quite detailed when is involving a big quantity of data (Jamaludin et al., 2020). The advantage of PRISMA can help researcher to produce a 
qualitative report through a specific process. Advantages of using a systematic review method with the PRISMA is the articles obtained are from the trusted and quality database. Furthermore, it is recognized by all researchers and also help the author from wasting time and wondering if the articles they have had enough (Pollock \& Berge, 2018). According to Moher et al (2009), PRISMA helps the author traces the articles according to the objectives of the study through four processes following, namely the identification process, screening, eligibility and inclusion.

Hence, this study used two (2) major online databases, which are Scopus and Web of Science (WOS). This database is quite qualified for this field of study. According to Xiao and Watson (2019), none of the databases are complete, so they suggest to use more than one database. There is no specification of the type of database is used, as long it goes through a rigorous process. So, it is labeled as a systematic literature analysis (Mohamed Shaffril et al., 2019). In the first stage, that is introduction, several keywords are used to identify articles that are relevant to this study. The main keywords selected for inclusion in this study were "perception", "ICT", "teachers" and "mathematics". Other than that, the use of alternative and synonymous terms used are "educators" or "schoolteachers". The word AND is inserted into the keywords to wider the range of findings and expanding the search into specialized studies about teachers' perception and OR operators to accommodate alternative spellings and synonym words (Aliyu, 2017) as in Table 1.

Table 1. Database source and search series (Search String)

\begin{tabular}{|c|c|}
\hline Database & Keyword Order Sequences and Boolean Operators \\
\hline Scopus & $\begin{array}{l}\text { TITLE-ABS-KEY (("teachers" OR “school teachers" OR "educators" OR } \\
\text { "lecturers") AND ("ICT" OR “technology") AND ("perception" OR "opinion" OR } \\
\text { "view point") AND ("mathematics")) }\end{array}$ \\
\hline $\begin{array}{l}\text { Web of } \\
\text { Science } \\
\text { (WOS) }\end{array}$ & $\begin{array}{l}\text { TS= (("teachers" OR "school teachers" OR "educators" OR "lecturers") AND } \\
\text { ("ICT" OR "technology") AND ("perception" OR "opinion" OR "view point") } \\
\text { AND ("mathematics teachers")) }\end{array}$ \\
\hline
\end{tabular}

The survey in this study was conducted relying on two major journal databases, namely Scopus and Web of Science (WOS). Scopus is a site that claim to be the largest single abstract and index database ever ((Burnham, 2006), while WOS is world's oldest site that help researchers to search and discover across many fields and disciplines (Birkle, Pendlebury, Schnell, \& Adams, 2020). In a way of specifically, Scopus indexed a total of 525 journals related to teachers' perception towards ICT while WOS indexed 172 journals related to the study of teachers' perception towards ICT. Results from the search through two search engines, a total of 697 articles were found.

In the screening phase, by focusing on a few conditions before discarding and retrieving the articles. There are several articles writing search criteria have been set before starting the search process. First, the source of the article is limited to the last five years of publication from 2017 to 2021 . The purpose is to get the latest information on teachers' perception towards ICT integrations in mathematics in the world of education. Selected articles have only empirical data only. In addition, the literature of this study must also consist of journal articles only. Besides that, the selection criteria for selected articles also included only involving open access articles. The purpose is to facilitate the process of acquiring and 
downloading articles. The preliminary survey was conducted based on title articles, abstract and keywords. Full text is searched and read for articles that meet the criteria qualifications based on title and abstract and determine whether the article will be retained or excluded in the last search or not. Table 2 below briefly describe the criteria for acceptance and rejection.

Table 2. The eligibility and exclusion criteria

\begin{tabular}{lll}
\hline General Criteria & $\begin{array}{l}\text { Eligibility } \\
\text { (Acceptance Criteria) }\end{array}$ & $\begin{array}{l}\text { Exclusion } \\
\text { (Rejection Criteria) }\end{array}$ \\
\hline $\begin{array}{l}\text { Year of Publication } \\
\text { Document Type }\end{array}$ & $\begin{array}{l}<2017-2021 \\
\text { Journal Articles }\end{array}$ & $\begin{array}{l}\text { Journal (systematic review), } \\
\text { book series, books, chapter in } \\
\text { book, conference proceeding }\end{array}$ \\
& & Excluded English \\
\hline Language & English & ing
\end{tabular}

After examined, a total of 29 duplicate articles were issued making it only 668 articles left. Article then screened into empirical studies and studies that were not conducted in that period. Finally, as many as 30 articles were selected based on the accepted criteria using the PRISMA method and analysed to achieve the purpose of this systematic literature review. Figure 1 shows the PRISMA flow chart in this study adapted and modified from Moher et al., (2009). 

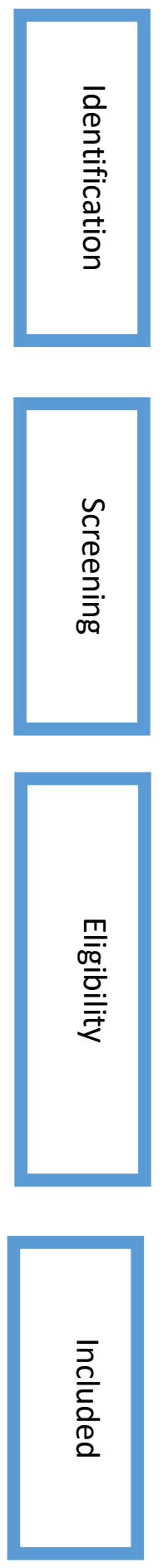
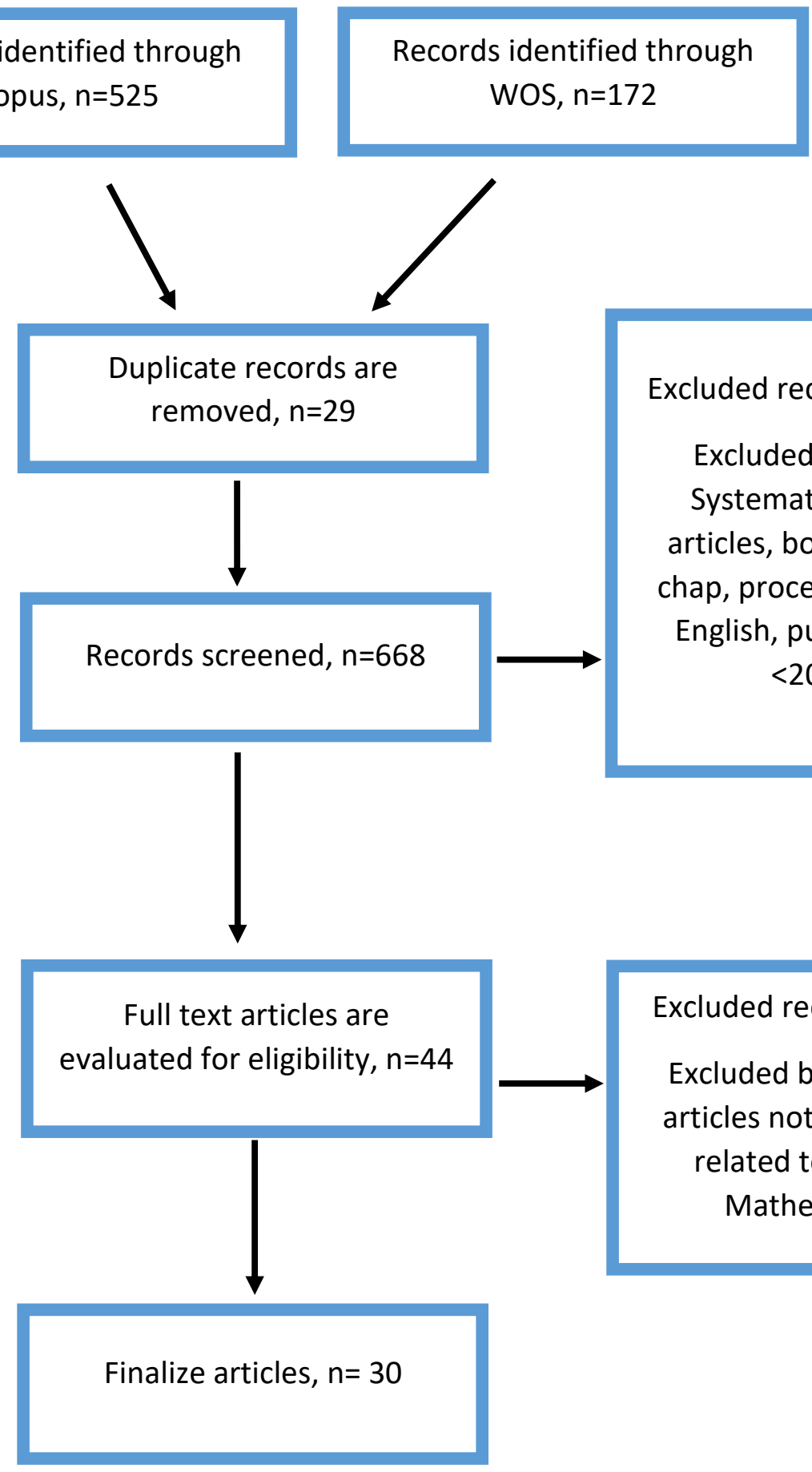

Excluded records, $n=624$

Excluded because

Systematic review articles, books, books chap, proceeding, nonEnglish, published in $<2017$

Figure 1 PRISMA flow chart

(Adapted from Moher et al. 2009)

\section{Results}

Finally, after four stages to determine which articles can be reviewed, 30 articles were identified with teachers' perception towards ICT integration in mathematics classroom. To answer the first research question, the findings of the study will analyse about (1) countries 
DEVELOPMENT

Vol. 10, No. 3, 2021, E-ISSN: 2226-6348 @ 2021 HRMARS

in where the study was performed, (2) the study design (methods used and approaches) and (3) year of studies.

\section{Country Study}

Table 3 shows the 15 countries where the study was conducted. Based on the table, can conclude that majority of the studies were conducted the Asian continent. Turkey became the highest country of the study related to ICT integration in mathematics classroom. Turkey has the highest country of the study, a total of 10 studies, followed by United States 4 studies, while Australia, South Africa and Spain with 2 studies and the rest only have 1 study.

Table 3. Countries of Study

\begin{tabular}{|c|c|c|c|}
\hline Continent & Country & $\mathbf{N}$ & Articles \\
\hline \multirow[t]{7}{*}{ Asia } & Cyprus & 1 & Tsouccas \& Meletiou-Mavrotheris (2019) \\
\hline & India & 1 & Bora \& Ahmed (2020) \\
\hline & Indonesia & 1 & Haviz \& Maris (2020) \\
\hline & Israel & 1 & Daher and Shahbari (2020) \\
\hline & Saudi Arabia & 1 & Aldahmash et al. (2019) \\
\hline & South Korea & 1 & Kim et al. (2019) \\
\hline & Turkey & 10 & $\begin{array}{l}\text { Karatas et al. (2017); Ibili et al. (2019); Birgin et al. } \\
\text { (2020); Akran \& Aşiroğlu (2018); Sahal \& Ozdemir } \\
\text { (2020); Şen \& Hava (2020); Yildirim \& Sidekli } \\
\text { (2018); Yıldırım \& Türk (2018); Birgin et al. (2020); } \\
\text { Faruk Islim et al. (2018) }\end{array}$ \\
\hline \multirow[t]{2}{*}{ Africa } & Nigeria & 1 & Sunday et al. (2019) \\
\hline & South Africa & 2 & $\begin{array}{l}\text { Naidoo \& Singh-Pillay (2020); Ndlovu \& Mostert } \\
\text { (2018) }\end{array}$ \\
\hline \multirow[t]{4}{*}{ Europe } & Ireland & 1 & Ní Fhloinn et al. (2018) \\
\hline & Russia & 1 & Anisimova et al. (2020) \\
\hline & Spain & 2 & $\begin{array}{l}\text { Gómez-García et al. (2020); Trujillo-Torres et al. } \\
\text { (2020) }\end{array}$ \\
\hline & Sweden & 1 & Humble et al. (2020) \\
\hline $\begin{array}{l}\text { North } \\
\text { America }\end{array}$ & United States & 4 & $\begin{array}{l}\text { Herro \& Quigley (2017); Nowikowski (2017); } \\
\text { Johnson et al. (2021); Rowe et al. (2020) }\end{array}$ \\
\hline Australia & Australia & 2 & Attard \& Holmes (2020); Brown (2017) \\
\hline
\end{tabular}

\section{Research Design and Research Approaches}

The method for each study analysed were coded based on the research design. List of research design used were: (1) Case Study (2) Survey Study, (3) Experimental Study (4) Phenomenological Study, (5) Cross-Sectional Study, (6) Explanatory Sequential study, (7) Concurrent Embedded Design, and (8) Concurrent Triangulation Design.

Table 4 below shows the study design used together with the types of respondents involved in each relevant study. The trend in terms of research design and study sample for 30 articles. A total of 11 articles are focused on case study followed by survey study with 9 articles. Findings from the review suggest that secondary in-service teachers have been selected in most studies following by pre-service teachers and primary in-service teachers. 
The are 3 articles focused on both primary and secondary teachers. While only one sample of study which focuses on both pre-service and in-service teachers and lecturers of university.

Table 4. Frequency of Research Design and Types of Respondents

\begin{tabular}{|c|c|c|c|c|c|c|}
\hline Research Design & $\begin{array}{l}\text { Pre- } \\
\text { Service } \\
\text { Teachers }\end{array}$ & $\begin{array}{l}\text { In- } \\
\text { Service } \\
\text { Teachers } \\
\text { (Primary) }\end{array}$ & $\begin{array}{l}\text { In-Service } \\
\text { Teachers } \\
\text { (Secondary) }\end{array}$ & $\begin{array}{l}\text { Primary \& } \\
\text { Secondary } \\
\text { Teachers }\end{array}$ & $\begin{array}{l}\text { Pre } \& \text { In- } \\
\text { Service } \\
\text { Teachers }\end{array}$ & $\begin{array}{l}\text { Lecturers } \\
\text { University }\end{array}$ \\
\hline $\begin{array}{l}\text { Case Study } \\
(n=11)\end{array}$ & 4 & 1 & 5 & 1 & & \\
\hline $\begin{array}{l}\text { Survey Study } \\
(n=9)\end{array}$ & 2 & 2 & 3 & 1 & 1 & \\
\hline $\begin{array}{l}\text { Experimental } \\
\text { Study } \\
(n=1)\end{array}$ & & & & 1 & & \\
\hline $\begin{array}{l}\text { Phenomenological } \\
\text { Study } \\
(n=2)\end{array}$ & 1 & 1 & & & & \\
\hline $\begin{array}{l}\text { Cross-Sectional } \\
\text { Study } \\
(n=2)\end{array}$ & & & 2 & & & \\
\hline $\begin{array}{l}\text { Explanatory } \\
\text { Sequential Study } \\
(n=2)\end{array}$ & 1 & & & & & 1 \\
\hline $\begin{array}{l}\text { Concurrent } \\
\text { Embedded Design } \\
(n=2)\end{array}$ & 1 & 1 & & & & \\
\hline $\begin{array}{l}\text { Concurrent } \\
\text { Triangulation } \\
\text { Design } \\
(n=1)\end{array}$ & & & 1 & & & \\
\hline
\end{tabular}

An analysis of research approaches also has been conducted. The results found that the type of approach in the study used was quantitative, qualitative as well as mixed method (a combination of quantitative and qualitative). Table 5 below shows the numbers and percentages for the types of approach researchers used. Qualitative research recorded the highest percentage which is $43.4 \%$ with 13 articles. Quantitative research, on the other hand, recorded $40 \%$ (12 articles) while mixed method recorded the lowest percentage which is $16.7 \%$ (5 articles). 
Table 5. Research Approaches

\begin{tabular}{|c|c|}
\hline Type of Approaches & Authors (Years) \\
\hline $\begin{array}{l}\text { Qualitative } \\
(n=13)\end{array}$ & $\begin{array}{l}\text { Akran \& Aşiroğlu (2018); Attard \& Holmes (2020); Brown (2017); } \\
\text { Daher \& Shahbari (2020); Faruk Islim et al. (2018); Herro \& } \\
\text { Quigley (2017); Humble et al. (2020); Naidoo \& Singh-Pillay } \\
\text { (2020); Nowikowski (2017); Sahal \& Ozdemir (2020); Şen \& Hava } \\
\text { (2020); Tsouccas \& Meletiou-Mavrotheris (2019); Yıldırım \& Türk } \\
\text { (2018) }\end{array}$ \\
\hline $\begin{array}{l}\text { Quantitative } \\
(n=12)\end{array}$ & $\begin{array}{l}\text { Aldahmash et al. (2019); Anisimova et al. (2020); Birgin et al. } \\
\text { (2020); Bora \& Ahmed (2020); Gómez-García et al. (2020); lbili et } \\
\text { al. (2019); Karatas et al. (2017); Kim et al. (2019); Ní Fhloinn et al. } \\
\text { (2018); Rowe et al. (2020); Sunday et al. (2019); Trujillo-Torres et } \\
\text { al. (2020) }\end{array}$ \\
\hline $\begin{array}{l}\text { Mixed Method } \\
(n=5)\end{array}$ & $\begin{array}{l}\text { (Birgin et al., 2020; Haviz \& Maris, 2020; Johnson et al., 2021; } \\
\text { Ndlovu \& Mostert, 2018; Yildirim \& Sidekli, 2018) }\end{array}$ \\
\hline
\end{tabular}

\section{Year of Studies}

An analysis of the frequency of the study over the five latest years is carried out and presented in a table. Table 6 shows the number and percentage of articles by year. Based on the table, the highest percentage is in the year 2020 with 15 articles and recorded 44.1\%. Articles for 2019, 2018 and 2017 recorded the same percentage as 17.6\% respectively. While 2021 recorded the lowest percentage of $2.9 \%$, this is due to the study done in early 2021 .

Table 6. Frequency of Studies

\begin{tabular}{lll}
\hline Years & Numbers of Article & Percentage \\
\hline 2017 & 6 & $17.6 \%$ \\
2018 & 6 & $17.6 \%$ \\
2019 & 6 & $17.6 \%$ \\
2020 & 15 & $44.1 \%$ \\
2021 & 1 & $2.9 \%$ \\
\hline
\end{tabular}

\section{Fields of Studies}

For the second research question, the distribution of articles according to the study field was conducted. The study field in this study can be divided into seven groups. Table 7 indicates the frequency for the study area. As a result of the analysis found, $40 \%$ of articles is about the use of ICT. As for STEM, the study covered $26.7 \%$ while for the field study of STEAM and blended learning recorded $10 \%$ respectively. Percentage for TPACK recorded $6.7 \%$ while flipped classroom and $21^{\text {st }}$ century learning only recorded at $1 \%$. 
Table 7. Study Field

\begin{tabular}{lll}
\hline Study Field & Numbers of Article & Percentage \\
\hline 21st- Century Learning & 1 & $3.3 \%$ \\
Blended Learning & 3 & $10 \%$ \\
Flipped Classroom & 1 & $3.3 \%$ \\
STEAM & 3 & $10 \%$ \\
STEM & 8 & $26.7 \%$ \\
TPACK & 2 & $6.7 \%$ \\
Use of ICT & 12 & $40 \%$ \\
\hline
\end{tabular}

\section{Discussion}

In this 21st century, teachers need to know not only how to use the technology but when and why use it. To get the results of technology integration to be effective, it requires ongoing collaboration among teachers, administrators, and parents to encourage student learning. It is very important to acknowledge teachers' perception towards the ICT integration in mathematics classroom.

Findings reveal that most studies were conducted around Asian continent. Majority studies were conducted in Turkey follow by United States. Other countries are very lacking in conducting research for teachers' perception towards ICT integrations especially in mathematics. In terms of methodology, the most research design that had been carry out is case study follow by survey study. According to Bell and Waters (2014), case study can provides an opportunity for in-depth study of one aspect of the problem. While survey is aimed to obtain information from a representative selection of population to present the survey results as representative of the entire population.

Analysis of the systematic literature review found that there are still many relevant studies in the context of mathematics education is carried out. Study on teachers' perception towards $\mathrm{CIT}$ integration in mathematics classroom is still actively practiced by researchers to this day. From analysis, it was found that the distribution of this study over the last five years is almost uniform except in year 2020 where's a drastic increase happen in year 2020. According to Nguyen et al. (2020), pandemic Covid-19 had caused a vast increase in digital communication and force the education system to be conduct online. This showed that this study is still relevant up to the present and still is one of the areas chosen by the researchers. Based on the results, we also can conclude that many countries still integrating ICT in teaching and learning mathematics.

The findings also show that the majority studies are conducted qualitatively compared to quantitatively. This type of research for studies can be implemented in three forms namely quantitative, qualitative or a combination of quantitative and qualitative. From the results of the analysis, it is found that the study has been implemented in all three approaches. According to Chua (2014), quantitative approach aims to test theories, show differences as well as show relationships. This form of research is more about making generalization. Meanwhile, qualitative approach is more about improving understanding, explaining statements and explaining events verbally (Chua, 2014).

Besides that, the majority study field in this study is the use of ICT follow by STEM. Indeed, it can be seen that many studies have examined the perception of teachers. Almost 
all the relevant study findings showed a positive perception towards ICT integration in mathematics classroom. However, there are also minority studies that reported a negative perception of ICT integration. Akran and Aşiroğlu (2018) stated that mathematics teachers have positive perception on STEM education in their study. While Yıldırım and Türk (2018) claims that STEM education is a useful education concept, but some problems may be encountered in the process of STEM education. In addition, it was also found that after STEM training, teachers' views on STEM education have undergone positive changes.

Mastering the use of ICT will help teachers provide effective guidance using existing technical tools. It is also hope that future study about this field can be further multiplied in the context of mathematics education. However, the number of studies focusing in Malaysian mathematics education is lack. Therefore, the results of this study are expected to provide a deep understanding so that such studies can be implemented in the context of mathematics education in Malaysia.

\section{Conclusion}

Integration ICT in mathematics classroom is increasingly emphasized in the field of education, especially in this era of transformation of the education system and the pandemic covid-19 season. Results shows that most of the country's research comes from Turkey followed by the United States. Meanwhile, the frequency of studies in this field is uniform for 2017 to 2019, but it is increasing in year 2020. This may be caused by the Convid-19 pandemic. Besides that, the most research design that had been carry out is case study and conducted qualitatively. Majority study field discuss about the use of ICT in mathematics classroom.

\section{Implication and Contribution of the Research}

This systematic literature review aims to contribute to knowledge as well as being able to provide enlightenment through article analysis about teachers' perception towards ICT integration in mathematics classroom. Some related studies may have been omitted from this review because the screening process may also have screened out some interesting studies on teachers' perception towards integrating ICT in mathematics classroom. Based on the literature search, this study is relevant as there are still not many systematic literature reviews found focuses on ICT integration in mathematics classroom. There are many studies on teachers' perception towards ICT integration but not doing in mathematics classroom. Thus, this systematic literature review is helpful in shedding light on the teachers' perception towards ICT integration in mathematics classroom. Information that obtained from multicountry studies provide meaningful input in this study. This study is expected to provide ideas to analyse teachers' perception towards ICT integrations in mathematics classroom. The findings can be used in guiding future research to be conducted by broadening the respondent to beyond teachers and students.

\section{References}

Akran, S. K., \& Aşiroğlu, S. (2018). Perceptions of teachers towards the stem education and the constructivist education approach: Is the constructivist education approach preparatory to the STEM education? Universal Journal of Educational Research, 6(10), 2175-2186. https://doi.org/10.13189/ujer.2018.061016

Aldahmash, A. H., Alamri, N. M., Aljallal, M. A., \& Bevins, S. (2019). Saudi Arabian science and mathematics teachers' attitudes toward integrating STEM in teaching before and after 
participating in a professional development program. Cogent Education, 6(1). https://doi.org/10.1080/2331186X.2019.1580852

Ali, W. (2018). Teachers ' perceptions of ICT integration as a pedagogic reform in classroom instruction. IOSR Journal Of Humanities And Social Science (IOSR-JHSS), 23(10), 14-31. https://doi.org/10.9790/0837-2310091431

Aliyu, M. B. (2017). Efficiency of boolean search strings for information retrieval. American Journal of Enginnering Research, 6(11), 216-222.

Anisimova, T. I., Sabirova, F. M., \& Shatunova, O. V. (2020). Formation of design and research competencies in future teachers in the framework of STEAM education. International Journal of Emerging Technologies in Learning, 15(2), 204-217. https://doi.org/10.3991/ijet.v15i02.11537

Attard, C., \& Holmes, K. (2020). An exploration of teacher and student perceptions of blended learning in four secondary mathematics classrooms. Mathematics Education Research Journal. https://doi.org/10.1007/s13394-020-00359-2

Banda, M., Hamaundu, M., \& Mwansa, B. M. (2020). Views of teachers towards ICT integration in history. International Journal of Humanities, Social Sciences and Education, 7(6), 116122. https://doi.org/10.20431/2349-0381.0706013

Belay, M. T., Khatete, D. D. W., \& Mugo, D. B. C. (2020). Teachers' attitude towards integrating ICT in classroom instruction in teaching and learning biology in secondary schools in the Southern Region, Eritrea. Journal of Education and Practice, 4(1), 1-18. https://doi.org/10.47941/jep.393

Bell, J., \& Waters, S. (2014). Doing your research project: A guide for first-time researchers (6th ed.). Maidenhead: McGraw-Hill Education.

Birgin, O., Uzun, K., \& Mazman Akar, S. G. (2020). Investigation of Turkish mathematics teachers' proficiency perceptions in using information and communication technologies in teaching*. Education and Information Technologies, 25(1), 487-507. https://doi.org/10.1007/s10639-019-09977-1

Birkle, C., Pendlebury, D. A., Schnell, J., \& Adams, J. (2020). Web of science as a data source for research on scientific and scholarly activity. Quantitative Science Studies, 1(1), 363376. https://doi.org/10.1162/qss_a_00018

Bora, A., \& Ahmed, S. (2020). Secondary school mathematics teachers' perceptions on technological modern teaching approaches. International Journal of Scientific and Technology Research, 9(1), 2418-2423.

Brown, J. P. (2017). Teachers' perspectives of changes in their practice during a technology in mathematics education research project. Teaching and Teacher Education, 64, 52-65. https://doi.org/10.1016/j.tate.2017.01.022

Burnham, J. F. (2006). Scopus database: A review. Biomedical Digital Libraries, 3(1), 1-8. https://doi.org/10.1186/1742-5581-3-1

Chua, Y. P. (2014). Kaedah penyelidikan (3rd ed.). Shah Alam: McGraw-Hill.

Daher, W., \& Shahbari, J. A. (2020). Design of STEM activities: Experiences and perceptions of prospective secondary school teachers. International Journal of Emerging Technologies in Learning, 15(4), 112-128. https://doi.org/10.3991/ijet.v15i04.11689

Dong, C. (2018). Preschool teachers' perceptions and pedagogical practices: Young children's use of ICT. Early Child Development and Care, 188(6), 635-650.

https://doi.org/10.1080/03004430.2016.1226293

Faruk Islim, O., Ozudogru, G., \& Sevim-Cirak, N. (2018). The use of digital storytelling in 
elementary math teachers' education. Educational Media International, 55(2), 107-122. https://doi.org/10.1080/09523987.2018.1484045

Gómez-García, M., Hossein-Mohand, H., Trujillo-Torres, J. M., \& Hossein-Mohand, H. (2020). The training and use of ICT in teaching perceptions of melilla's (spain) mathematics teachers. Mathematics, 8(10). https://doi.org/10.3390/MATH8101641

Haviz, M., \& Maris, I. M. (2020). Measuring mathematics and science teachers' perception on thinking and acting in 21st-century learning. Journal for the Education of Gifted Young Scientists, 8(4), 1319-1328. https://doi.org/10.17478/JEGYS.747395

Herro, D., \& Quigley, C. (2017). Exploring teachers' perceptions of STEAM teaching through professional development: implications for teacher educators. Professional Development in Education, 43(3), 416-438. https://doi.org/10.1080/19415257.2016.1205507

Humble, N., Mozelius, P., \& Sällvin, L. (2020). Remaking and reinforcing mathematics and technology with programming - teacher perceptions of challenges, opportunities and tools in K-12 settings. International Journal of Information and Learning Technology, 37(5), 309-321. https://doi.org/10.1108/IJILT-02-2020-0021

Ibili, E., Resnyansky, D., \& Billinghurst, M. (2019). Applying the technology acceptance model to understand maths teachers' perceptions towards an augmented reality tutoring system. Education and Information Technologies, 24(5), 2653-2675. https://doi.org/10.1007/s10639-019-09925-z

Jamaludin, N. I., Shahimi, S., Bibi, L., \& Hameed, M. (2020). Elemen kepercayaan sebagai teras sumbangan melalui pendanaan awam bertujuan kebajikan. Asian Journal of Accounting and Governance, 13, 55-65. https://doi.org/10.17576/ajag-2020-13-05

Jepkorir, M. (2017). Teachers' perceptions on ICT integration in secondary schools in Tinderet sub-county. Journal of Education and Practice, 8(18), 136-143. Retrieved from https://iiste.org/Journals/index.php/JEP/article/view/37670/0

Johnson, T. M., Byrd, K. O., \& Allison, E. R. (2021). The impact of integrated STEM modeling on elementary preservice teachers' self-efficacy for integrated STEM instruction: A coteaching approach. School Science and Mathematics, 121(1), 25-35. https://doi.org/10.1111/ssm.12443

Karatas, I., Tunc, M. P., Yilmaz, N., \& Karaci, G. (2017). An investigation of technological pedagogical content knowledge, self-confidence, and perception of pre-service middle school mathematics teachers towards instructional technologies. Educational Technology and Society, 20(3), 122-132.

Katsarou, D. (2020). Views and perceptions of teachers in special education in Greece regrading ICT. European Journal of Educational Research, 5(3), 40-59. https://doi.org/10.5281/zenodo.3633839

Kim, M. K., Lee, J. Y., Yang, H., Lee, J., Jang, J. N., \& Kim, S. J. (2019). Analysis of elementary school teachers' perceptions of mathematics-focused STEAM education in Korea. Eurasia Journal of Mathematics, Science and Technology Education, 15(9), 1-13. https://doi.org/10.29333/ejmste/108482

Marbán, J. M., \& Mulenga, E. M. (2019). Pre-service primary teachers' teaching styles and attitudes towards the use of technology in mathematics classrooms. International Electronic Journal of Mathematics Education, 14(2), 253-263.

https://doi.org/10.29333/iejme/5649

Mensah, F. S. (2017). Ghanaian mathematics teachers' use of ICT in instructional delivery. 
DEVELOPMENT

Vol. 10, No. 3, 2021, E-ISSN: 2226-6348 @ 2021 HRMARS

Global Journal of Human-Social Science, 17(8), 1-13.

Shaffril, M. H. A., Samah, A. A., Samsuddin, S. F., \& Ali, Z. (2019). Mirror-mirror on the wall, what climate change adaptation strategies are practiced by the Asian's fishermen of all? Journal of Cleaner Production, 232, 104-117.

https://doi.org/10.1016/j.jclepro.2019.05.262

Moher, D., Liberati, A., Tetzlaff, J., Altman, D. G., Altman, D., Antes, G., Tugwell, P. (2009). Preferred reporting items for systematic reviews and meta-analyses: The PRISMA statement. PLoS Medicine, 6(7). https://doi.org/10.1371/journal.pmed.1000097

Mustam, A. A., \& Adnan, M. (2019). Perception of primary mathematics teachers on STEMoriented teaching and learning. Journal of Physics: Conference Series, 1227(1), 1-8. https://doi.org/10.1088/1742-6596/1227/1/012009

Mwendwa, N. K. (2017). Perception of teachers and principals on ICT integration in the primary school curriculum in Kitui County, Kenya. Eropean Journal of Education Studies, 3(7), 408-430. https://doi.org/10.5281/zenodo.824829

Naidoo, J., \& Singh-Pillay, A. (2020). Teachers' perceptions of using the blended learning approach for stem-related subjects within the fourth industrial revolution. Journal of Baltic Science Education, 19(4), 583-593. https://doi.org/10.33225/jbse/20.19.583

Nasreen, N., \& Chaudhary, F. (2018). Perception of preservice teachers towards ICT integration in teacher education in India. ACM International Conference Proceeding Series, 11-14. https://doi.org/10.1145/3300942.3300948

Ndlovu, M. C., \& Mostert, I. (2018). Teacher perceptions of moodle and throughput in a blended learning programme for in-service secondary school mathematics teachers. Africa Education Review, 15(2), 131-151. https://doi.org/10.1080/18146627.2016.1241667

Nguyen, M. H., Gruber, J., Fuchs, J., Marler, W., Hunsaker, A., \& Hargittai, E. (2020). Changes in digital communication during the COVID-19 global pandemic: implications for digital inequality and future research. Social Media and Society, 6(3). https://doi.org/10.1177/2056305120948255

Ní Fhloinn, E., Nolan, B. C., Hoehne Candido, G., \& Guerrero, S. M. (2018). Pre-service versus in-service mathematics teachers' opinions of mathematics reform in post-primary schools in Ireland. Irish Educational Studies, 37(4), 431-452.

https://doi.org/10.1080/03323315.2018.1512884

Nowikowski, S. H. (2017). Successful with STEM? A qualitative case study of pre-service teacher perceptions. Qualitative Report, 22(9), 2312-2333. https://doi.org/10.46743/2160-3715/2017.2893

Ogegbo, A. A., \& Aina, A. (2020). Early childhood development teachers' perceptions on the use of technology in teaching young children. South African Journal of Childhood Education, 10(1), 1-10. https://doi.org/10.4102/sajce.v10i1.880

Pollock, A., \& Berge, E. (2018). How to do a systematic review. International Journal of Stroke, 13(2), 138-156. https://doi.org/10.1177/1747493017743796

Redmond, P., \& Lock, J. (2019). Secondary pre-service teachers' perceptions of technological pedagogical content knowledge (TPACK): What do they really think? Australasian Journal of Educational Technology, 35(3), 45-54. https://doi.org/10.14742/ajet.4214

Rowe, S., Riggio, M., De Amicis, R., \& Rowe, S. R. (2020). Teacher perceptions of training and pedagogical value of cross-reality and sensor data from smart buildings. Education Sciences, 10(9), 1-18. https://doi.org/10.3390/educsci10090234 
Sahal, M., \& Ozdemir, A. S. (2020). Pre-service primary teachers' views and use of technology in mathematics lessons. Research in Learning Technology, 28(1063519), 1-14. https://doi.org/10.25304/rlt.v28.2302

Sang, G., Liang, J. C., Chai, C. S., Dong, Y., \& Tsai, C. C. (2018). Teachers' actual and preferred perceptions of twenty-first century learning competencies: A Chinese perspective. Asia Pacific Education Review, 19(3), 307-317. https://doi.org/10.1007/s12564-018-9522-0

Şen, E. Ö., \& Hava, K. (2020). Prospective middle school mathematics teachers' points of view on the flipped classroom: The case of Turkey. Education and Information Technologies. https://doi.org/10.1007/s10639-020-10143-1

Sunday, U. C., Joseph, A. J., Eunice, O., Ugwuanyi, C. C., Elochukwu, I. F., Agnes, O. O., ... Basil, C. O. (2019). Information and Communication Technology (ICT) capacity building needs for 21st century classroom instructional delivery: Perceptions of science and mathematics teachers. Journal of Engineering and Applied Sciences, 14(1), 270-274. https://doi.org/10.3923/jeasci.2019.270.274

Taghizadeh, M., \& Yourdshahi, H. Z. (2020). Integrating technology into young learners' classes: language teachers' perceptions. Computer Assisted Language Learning, 33(8), 982-1006. https://doi.org/10.1080/09588221.2019.1618876

Trujillo-Torres, J. M., Hossein-Mohand, H., Gómez-García, M., Hossein-Mohand, H., \& Cáceres-Reche, M. P. (2020). Mathematics teachers' perceptions of the introduction of ict: The relationship between motivation and use in the teaching function. Mathematics, 8(12), 1-17. https://doi.org/10.3390/math8122158

Tsouccas, L. F., \& Meletiou-Mavrotheris, M. (2019). Enhancing in-service primary teachers' technological, pedagogical and content knowledge on mobile mathematics learning. International Journal of Mobile and Blended Learning, 11(3), 1-18.

https://doi.org/10.4018/IJMBL.2019070101

Umugiraneza, O., Bansilal, S., \& North, D. (2018). Exploring teachers' use of technology in teaching and learning mathematics in KwaZulu-Natal schools. Pythagoras-Journal of the Association for Mathematics Education of South Africa, 39(1), 1-14. https://doi.org/10.4102/pythagoras.v39i1.342

Xiao, Y., \& Watson, M. (2019). Guidance on conducting a systematic literature review. Journal of Planning Education and Research, 39(1), 93-112. https://doi.org/10.1177/0739456X17723971

Yildirim, B., \& Sidekli, S. (2018). STEM applications in mathematics education: The effect of STEM applications on different dependent variables. Journal of Baltic Science Education, 17(2), 200-214. https://doi.org/10.33225/jbse/18.17.200

Yıldırım, B., \& Türk, C. (2018). Opinions of middle school science and mathematics teachers on STEM education. World Journal on Educational Technology: Current Issues, 10(2), 7078. https://doi.org/10.18844/wjet.v10i2.3426

Zubković, B. R., Pahljina-Reinić, R., \& Kolić-Vehovec, S. (2017). Predictors of ICT Use in Teaching in Different Educational Domains. European Journal of Social Sciences Education and Research, 11(2), 145-154. https://doi.org/10.26417/ejser.v11i2.p145154 